From 'for' to 'of': a typology of Maltese disability organisations

Anne-Marie Callus

This is an author produced version of a paper published in Disability \& Society. This paper has been peer-reviewed but does not include final publisher proof-corrections or journal pagination.

Citation for the published paper

Callus, Anne-Marie. (2014) From 'for' to 'of' : a typology of Maltese disability organisations, Disability \& Society, 29:1, 1-15, DOI: 10.1080/09687599.2013.776487 


\begin{abstract}
The main aim of this article is to adapt the Typology of Disability Organisations that Oliver devised, and subsequently developed further in 1990, to a different context, in this case the Maltese disability sector. The paper first traces the history of the disabled people's movement and presents Oliver's Typology, which makes a clear distinction between organisations for and of disabled persons. The article then highlights the main characteristics of the Maltese disability sector and develops the Typology of the organisations operating within that sector. It shows how it is nondisabled people that are mostly in control of disability organisations, and suggests ways in which there can be a stronger movement towards the development and strengthening of disabled people's organisations. The article shows how Oliver's Typology can be used flexibly and adapted to various contexts. It also shows how drawing up a Typology of Disability Organisations can shed light on the environment within which these organisations operate, identifying areas of strength and possible areas for growth.
\end{abstract}

Keywords: disabled people's movement; disability organisations

\title{
Points of interest
}

- The Typology of Disability Organisations that Oliver (1984) devised, and developed further in 1990, makes a clear distinction between organisations for and of disabled persons.

- The article adapts this Typology to the Maltese disability sector and shows how it is non-disabled people that are mostly in control of disability organisations.

- The article suggests ways in which there can be a stronger movement towards the development and strengthening of disabled people's organisations.

- The article shows how Oliver's Typology can be used flexibly and adapted to various contexts.

- The article also shows how drawing up a Typology of Disability Organisations can shed light on the environment within which these organisations operate, identifying areas of strength and possible areas for growth 


\section{The disabled people's movement}

In an article entitled 'The Other Movement that Rosa Parks Inspired', written shortly after her death in October 2005, Charles Wilson discusses how Parks's stand against racial discrimination in 1955, when she famously refused to give up her seat

to a white bus passenger, inspired American disabled people to protest about their inability to get onto physically inaccessible buses, a protest that in turn gave rise to an organised disability rights movement in the United States (Wilson 2005). As Barnes, Oliver, and Barton $(2002,4)$ state, the same pattern was repeated in the 1960s and 1970s in many countries, with disabled people mobilising into a civil rights movement '[i]nspired by the political and social upheavals of the period'. The formation and rise of the disability movement can be linked to disabled people's increased rejection of perceptions of disability as a personal tragedy that could only be alleviated through the intervention of non-disabled people, as exemplified for instance in Joseph Shapiro's (1993) book No Pity. The movement can also be seen as disabled people's struggle to exert control over their own lives and over the organisations representing them, as shown in the analysis of Canadian user-led disability organisations by Hutchison et al. (2007).

The issue of who runs disability organisations remains a crucial aspect of any discussion of the disability movement. Generally, organisations that are considered to form part of this movement are those that are led by disabled people themselves. Indeed, Oliver and Barnes state that they prefer the term 'disabled people's movement' and take exception to the fact that 'many traditional disability organizations have attempted to join the movement and now consider themselves to be part of it' $(2008,397)$.

Another issue that is raised through discussions of the disabled people's movement is its purported coherence. The concept of a movement rests on the assumption that there exists a coherent collectivity of different organisations that work in collaboration with each other towards the same aim. This may be true in a broad sense (Beckett 2006), but in reality there is a wide variety of disability organisations. In the context of the mental health sector, Peter Beresford argues that service-user groups have not always embraced the social model, and some 'continue to accept and internalise medicalised understandings of "mental illness" while others reject them' (Sheldon et al. 2007, 222). Another significant issue that this movement has to contend with is that not all those who have impairments readily identify themselves as disabled people, much less associate themselves with the disabled people's movement. This has been noted by several authors. Watson (2002) interviewed 28 disabled people, of whom only three identified themselves as being disabled. This is in line with Barnes and Mercer's (2010) assertion that many people who have an impairment do not see themselves as dis- abled persons, a situation that is also observed by Oliver (1984) and Shakespeare (2006).

In the Typology of British disability organisations developed by Oliver (1984) a clear distinction is made between 'organisations of and for the disabled' (Oliver 1984, 23; original emphasis). Broadly speaking, the latter are those organisations in which non-disabled people work on behalf 
of disabled people, while the former are ones that are run by disabled people themselves. As will be seen later, disabled people can be part of organisations for disabled people, while non-disabled people can be involved in organisations of disabled people, for instance in self-advocacy groups of people with intellectual disability. The Disabled Person's Organization (Bahamas) (2012), for instance, defines disabled people's organisations as those in which at least $51 \%$ of the membership are disabled people. The main point that needs to be made here is that organisations of disabled people can respond more effectively to the rallying cry of 'Nothing About Us Without Us' (Charlton 1998) and the growing realisation of the importance of including disabled people in decisions that concern them.

More recently, this was reflected in the direct involvement of disabled people and their representative organisations in drafting the United Nations Convention on the Rights of Persons with Disabilities (UNCRPD) and in this Convention's empha- sis on the importance of the direct involvement of disabled people in its implemen- tation. De Beco and Hoefmans $(2010,5)$ highlight the 'unprecedented... participation of persons with disabilities from across the globe and their representa- tive associations' in the drawing up of the Convention. The report also emphasises that for the UNCRPD to be successfully implemented there needs to be 'the active participation and inclusion of persons with disabilities themselves as well as their representative associations' (De Beco and Hoefmans 2010, 13).

In the light of this history, it is pertinent to examine the extent to which organi- sations within the disability sector of any country are representative of disabled people. (The disability sector is here taken to include the efforts, services and other activities that originate both from organisations for and organisations of disabled people, including the disabled people's movement, as it is understood by Barnes and Oliver [2008].) This exercise has been carried out by Hutchison et al. (2007), who provide an analysis of user-led organisations in Canada, focusing on four national organisations. Oliver (1984) presents a wider Typology of Disability Organisations operating in Britain at the time, adapting his original Typology in 1990, taking into account the way that disability organisations, and the disabled people's movement, had developed.

This article takes its cue from Oliver's Typology of Disability Organisations, applying it to the organisations that currently operate in Malta, a southern European small island state. The Typology thus developed is used to reflect upon how disability organisations, and especially disabled people's organisations, have grown in this country. The article also explores the re-adaptability in different contexts of Oliver's Typology and the extent to which examining the type of disability organisations operating within any one country can facilitate the understanding of how the disabled people's movement has developed within that country. Accordingly, it is useful to start with a look at Oliver's Typology. 


\section{Oliver's Typology}

Oliver (1984) first drew up the Typology on the basis of disability organisations operating in Britain at the time of writing and classified them according to the type of approach they employ. He identified organisations that use the part- nership approach and work in collaboration with government; organisations that employ the income approach, focusing on ensuring adequate incomes for disabled people; self-help organisations that attempt to improve the lives of their members; and, finally, organisations using the populist approach, which Oliver identifies as ones in which disabled people themselves take control. As pointed out above, a distinction is therefore made between organisations that are controlled by disabled people themselves, thus being organisations of disabled people, and those led by non-disabled people; that is, organisations for disabled people.

Six years later, Oliver (1990) revised the Typology and came up with five categories of disability organisations:

Type 1: partnership/patronage.

Type 2: economic/parliamentarian.

Type 3: consumerist/self-help.

Type 4: populist/activist.

Type 5: umbrella/coordinating.

As Oliver (1990) himself points out, the revisions made in the Typology reflect changes that had occurred in the British disability sector in the intervening period. Apart from elaborating on the categories he had used in 1984, Oliver subsumes the income approach category under 'economic/parliamentarian' and introduces a new category - umbrella/coordinating. This reflects the way in which organisations were working in collaboration with each other and the rise of organisations of disabled people - the umbrella/coordinating groups referred to by Oliver are all organisations of.

In fact, in the second Typology Oliver makes a much clearer distinction than previously between organisations for and of disabled people, with the last three cat- egories - consumerist, populist and umbrella - being clearly described as organisa- tions of, in contrast to the two other types partnership and economic - which are organisations for disabled people. Significantly, Oliver places organisations of dis- abled people (Types 3-5) firmly with the disability movement, unlike the other type of organisations. Furthermore, he makes the point that populist/activist organisations are 'often antagonistic to the partnership approach' (Oliver 1990, 118). This indi- cates the increased awareness by disabled people that, in order for their rights to be recognised, they needed to set up their own organisations and set their own agenda. Indeed, as Hurst (2005) describes in 
her account of Disabled Peoples' International, it was organisations of disabled people that developed the social model and effected a shift from a focus on disability as purely a medical matter to a position that equates disability with restrictions arising from the way society itself is organised (UPIAS 1976).

In the second version of the Typology, Oliver (1990) privileges organisations of disabled people, stating clearly that only they form part of the disability movement. In this statement, there is an undercurrent of mistrust towards organisations that are controlled by non-disabled people. This sentiment is also reflected in Oliver's review of Tom Shakespeare's Disability Rights and Wrongs, where he takes issue with Shakespeare when he 'suggests that the big charities have changed beyond rec- ognition and can now be trusted by disabled people' (Sheldon et al. 2007, 233).

Another important point that Oliver (1990) makes is that the rise of disabled people's organisations (i.e. organisations of disabled people) is a relatively recent development. The historical development of the different types of disability organisations can be traced in the Typology, with Type 5 organisations being the most recent and Type 1 organisations the longest established. The same observation is made by Hutchison et al. (2007), who record that the traditional Canadian disability organisations were mainly established in the 1950s, with user-led organisations emerging two decades later. Subsequent developments in Britain do not seem to have brought about new types of organisations. Indeed, when Barnes and Mercer (2010) adopted Oliver's revised Typology, the five different types remained unchanged. They only included the names of organisations under each category that had come into being since 1990. As Oliver $(1984,1990)$ points out, not all organisations will necessarily fit in neatly within any one category. Indeed, like most types of categorisations, the Typology needs to be used flexibly. However, it does provide a useful way of considering developments in the disability sector. The most significant development can be said to be the mobilisation of disabled people into their own organisations and the rise of disabled people's organisations that now co-exist with organisations run by non-disabled people.

Oliver's study of the type of disability organisations found in Britain therefore sheds light onto how the disability sector has developed in that country. It is instructive to now point out the main characteristics of the Maltese disability sector.

\section{The disability sector in Malta}

In their account of the development of the Maltese disability sector from the 1940s to the present, Camilleri and Callus (2001) point to two characteristics of this devel- opment that are of relevance to this article. The first is the way in which the main agents of change were not disabled people working within grassroots groups, but small groups made up of parents of disabled people and non-disabled persons who worked with the government of the day. The authors emphasise the role that parents played in these developments, stating that: 
in Malta most of the services available to disabled persons came about as a result of strong lobbying by different groups of parents ... rather than at the insistence of disabled persons themselves. (Camilleri and Callus 2001, 87)

This points to a disability sector that is mostly dominated not by disabled people but by other persons representing their interests.

This situation is confirmed by Azzopardi (2009), who presents statistics of the members of disability organisation committees in Malta. Out of the 288 people surveyed, 25\% were parents of disabled people, $18 \%$ professionals and $13 \%$ disabled people (taking into account that $41 \%$ of the 288 members of different committees are not identified according to a particular type). Azzopardi (2009) remarks that this preponderance of professionals, parents and non-disabled volunteers in the running of disability organisations in Malta is also borne out by the interviews that he carried out. It is a pattern that is also confirmed in the Typology of Maltese Disability Organisations that is the subject of this article.

Moreover, to return to Camilleri and Callus's (2001) account, it was parents themselves who introduced the social model, the disability movement's 'big idea' (Hasler 1993), to Malta in the late 1980s. This state of affairs gives rise to ques- tions about whether there can be said to be a disabled people's movement in Malta.

A second characteristic of the Maltese disability sector identified by these authors is the role of the Catholic Church in its development. Indeed, in the late 1940s, long before parents began lobbying on behalf of their disabled children, it was a priest, Monsignor Mikiel Azzopardi, who sought to improve the lot of disabled people. His work and achievements are referred to by Camilleri and Callus (2001) and have also been extensively written about by others, including Bonnici (2005) and Cuschieri (1995). The most significant achievement he is credited with is that of fighting against the prevailing association of disability with shame. Accounts of his life and work all refer to the disabled people he found living hidden in their family homes, sometimes locked in cellars or barns. He sought to improve their quality of life and in 1964 opened the Dar tal-Providenza, which is referred to in the Typology below. By even associating with disabled people, Monsignor Azzopardi helped start the removal of the stigma attached to them. In its place, the imagery of charity took root. Working as he did within the framework of the Catholic Church, it was almost inevitable for him to appeal to people's Christian values and Christ's exhortation to 'love one another'.

The organisations described in the Typology that follows have developed against the historical backdrop outlined above. 


\section{A Typology of Maltese Disability Organisations}

Most of the organisations referred to below are listed in Bezzina (2009). Information about them was gathered through various means. This included reference to organisations' websites, to brochures and other information published by the organisations themselves, and to articles that have appeared in local newspapers and magazines. Emails were sent to people involved in organisations about which no published information was available.

The Typology identifies six categories:

(1) Government organisations.

(2) Church-run organisations.

(3) Partnership organisations.

(4) Parent-led organisations.

(5) Disabled people's organisations.

(6) Umbrella organisations.

While obviously taking my cue from Oliver's Typology, my approach is somewhat different to his. First of all, rather than distinguishing between organisations according to the type of approach they adopt, I have categorised them according to the type of committee or board that governs each organisation. In this way, the focus is on constitutional arrangements of these organisations and essentially on whether they are organisations 'of' or 'for'. This helps provide a clear picture of the land- scape of the disability sector in Malta as it brings out distinctly who the key players in this sector have been. Secondly, Oliver does not include organisations that are run and funded entirely by the state in his Typology, since his analysis is based on the state's response to the different types of non-governmental organisations. I have preferred to include state-run organisations as a category in their own right in order to provide as comprehensive a picture as possible.

The different approach that I have adopted shows that changes to Oliver's Typology are both possible and necessary. The possibility of changing it comes out clearly in the Typology presented below. The necessity for this change evinces the intimate link between developments within any country's disability sector and the type of organisations operating within it.

\section{State-run organisations}

State-funded services for disabled people in Malta have been growing since the setting up of the first special schools in the 1950s (Camilleri and Callus 2001) and today cover the whole lifecourse. Assessments of disabled children are carried out at the Child Development and Assessment Unit, which also provides a therapy service. Once they reach school age, the vast majority of disabled children are included in mainstream schools (WHO 2011). In state schools, inclusion is 
managed by the Student Services Department, within the Directorate for Educational Ser- vices. This Department provides early intervention for pre-school disabled children, and educational and support services for disabled children up to the age of 16.

State-funded further education institutions, especially the University of Malta and the Malta College for the Arts, Science and Technology (MCAST), provide some support for disabled students on their campuses (University of Malta 2012a; National Commission Persons with Disability [KNPD] 2012b). MCAST also runs a vocational education programme specifically for people with intellectual disability (MCAST 2012).

After leaving formal education, disabled people can register with the Employ- ment and Training Corporation, which assesses disabled people registering for work and seeks job opportunities for them. The Corporation also runs a work exposure scheme for disabled people and a number of schemes subsidising the pay of disabled people as an incentive for employers to recruit them (ETC 2012). The employment rates for disabled people in Malta, however, remain very low. In 2005, the last year for which census figures were available at the time of writing, $14.6 \%$ of disabled people in Malta were working compared with $48 \%$ of non-disabled people (Bezzina, Callus, and Cardona 2009). Disabled people who cannot work are entitled to a non-contributory disability pension that is roughly equivalent to $55 \%$ of the minimum wage (KNPD 2010b). They can also earn the full minimum wage without seeing a reduction in their pension (MFEI 2011).

Other state-funded services for disabled people are provided by Agenzija Sapport, which provides social work, residential, day and community services for disabled people (A ġenzija Sapport 2012).

Finally, the KNPD is the coordinating organisation in the disability sector and is responsible for the monitoring and implementation of the Equal Opportunities (Persons with Disability) Act. It is also the independent mechanism for the UNCRPD (Laws of Malta 2000). Of all the state-run organisations mentioned here, KNPD is the only one in which disabled people exert significant control over the way that it is run. One-half of its Board members are disabled people or parents of disabled persons (KNPD 2012a), while the majority of its secretariat's staff are disabled people.

Despite the services provided by these state-funded entities and other Church- run and nongovernmental organisations referred to below, there continues to be a shortage of adequate services for disabled people, especially in terms of commu- nity-based supported living (Spiteri Gingell 2011). The lack of services, the few employment opportunities and the low level of the disability pension mean that for many disabled people financial independence, and therefore living an independent life, is an unrealistic prospect. As a consequence, disabled people continue to be dependent on their families and on what Gauci $(2008,6)$ calls 'the sometimes fickle goodwill of members of their families'. As a result, 'disabled people in Malta face a daily struggle to survive, leaving them with little time to organise, reflect and study’ (Camilleri 2006, 7). 


\section{Church-run organisations}

This category reflects the important role that the Catholic Church has played in developments in the Maltese disability sector, which has already been referred to. There are no known organisations in the disability sector that are affiliated with other faiths.

The Church has a Diocesan Commission for Persons with Disability (Archdiocese of Malta 2012). The stated aims of this Commission are promoting the rights of disabled persons especially in terms of spiritual development, promot- ing their inclusion in the life of the Church, providing spiritual support to their families, and striving to increase awareness of the situation of disabled persons within the Church.

Apart from this Commission, there are three other organisations that are part of the Catholic Church. These are the Dar tal-Providenza (which was set up by Monsi- gnor Mikiel Azzopardi as explained above), Dar Pirotta, and Fondazzjoni Arka (Dar tal-Providenza 2012; Wright 2007; Arka Foundation n.d.). The first two provide mainly long-term residential services but also some shortterm respite services. Arka, on the other hand, provides mainly short-term respite but also some long-term residential and day services. With the exception of the Dar tal-Providen- za, which is home to 120 disabled persons, these are community-based group homes. The founders of all three organisations were priests and the person at the helm of each organisation is also a priest.

\section{Partnership organisations}

This term is used here to refer to those organisations that are neither governmental nor part of the Catholic Church and whose boards or committees comprise profes- sionals and volunteers working in the sector as well as parents of disabled people and in some instances disabled persons. These organisations are therefore run by various people who work in partnership. In some cases, some board or committee members are disabled persons or parents of disabled persons. However, these are in the minority and the respective organisations cannot therefore be considered to be disabled people's or parent-led organisations.

The first non-governmental disability organisation to be set up in Malta in 1946, the Physically Handicapped Rehabilitation Fund, is a partnership organisation (PHRF 2012). Nearly seven decades later, there is a proliferation of partnership organisations, and this is the category with the largest amount of organisations. Three of these partnership organisations provide residential services. Fondazzjoni Nazareth runs three community-based group homes (The Times [Malta] 2009a); Fondazzjoni Wens runs a group home that is also based in the community (Ameen 2009); and the Foundation for Respite Care Services provides short-term respite and day services at Dar il-Kaptan (FRCS 2012). Despite its status as a non-govern- mental organisation, Fondazzjoni Nazaret was founded by a priest and is broadly run on the principles of L'Arche, an organisation established in the Roman Catholic tradition (L'Arche 2012). In the case of Fondazzjoni Wens, the Administrator is a disabled person. The majority of board members of the Foundation for Respite Care Services are parents of disabled persons and there is also a disabled person on the board. 
Another three partnership organisations - the Inspire Foundation, the Equal Part- ners Foundation and the Richmond Foundation - are major service providers in the disability sector in Malta (Inspire 2012, Equal Partners 2012; Richmond Foundation 2012). Most of the clients of the first two foundations are people with intellectual disability, while the latter caters for persons with mental health difficulties.

Other partnership organisations include those that provide competitive sport opportunities (such as Special Olympics [2012] and the Malta Wheelchair Dance Sport Association [MWDSA 2012]); those that organise social and other activities for their members (such as Striving Towards Ability Not Disability; STAND n.d.); and organisations that are impairment specific (such as the Gozo Association for the Deaf; GAD 2012), or even condition specific (such as the Multiple Sclerosis Society of Malta; MSSM 2012).

While these disability organisations have been placed under the 'partnership' category, some of them do have disabled people on their boards or committees. The Chair of Inspire, for instance, is a disabled person, while Special Olympics has a disabled person on their committee. The Ability for Disability Association (AFDA n.d.), which is based in the smaller island of Gozo, has an equal number of parents and people with intellectual disability together with volunteers and persons working in the disability sector.

\section{Parent-led organisations}

These are organisations whose committee members are all or almost all parents of disabled people. Their focus is often not only disabled people but on the whole family since, as Curry (2009) argues, it is the whole family that is affected by disability. Thus, activities are organised and support provided for the whole family. These organisations include the National Parents Society of Persons with Disability (NPSPD 2012), and the Down Syndrome Association (Malta) (DSAM 2012). Apart from the Physically Handicapped Rehabilitation Fund, these two are among the old- est established disability organisations in Malta and reflect the history of parents being among the first to lobby for the rights of disabled people in Malta. Camilleri and Callus (2001) record how the Parents' Society challenged an educational system that excluded many disabled children and how the early successes led to 'a small nucleus of parents ... to shift their focus away from the medical model of disability and to look for more enduring solutions through social change' (Camilleri and Callus 2001, 87).

The ADHD Family Support Group is also parent led and some of the parents themselves have attention-deficit hyperactivity disorder (ADHD Family Support Group 2012). Two parent-led organisations were set up in the last few years: Autism Parents Association (2012) and STARS (2012). 


\section{Disabled people's organisations}

These are organisations with at least one-half of the committee comprising disabled people. Significantly, most of these organisations were set up quite recently. This mirrors the development noted in Oliver's Typology. These organisations represent various impairment groups. Amputees for Amputees, the Muscular Dystrophy Group, and Living Ability Not Disability are composed of people with mobility impairments (The Times [Malta] 2009b; MDGM 2012; LAND 2012). The Deaf People Association is run by Deaf people who use Maltese Sign Language, and the Gozo Aid for the Visually Impaired, despite the for in its name, has a majority of people with visual impairments on its committee (Deaf People Association Malta 2012; Attard 2012). The Grupp Flimkien Naslu is a self-advocacy group that is similar to many People First groups in the United Kingdom (GFN n.d.), while Opening Doors is a theatre group led by people with intellectual disability and non- disabled people who work in the theatre (Opening Doors n.d.).

The work of these organisations is quite varied and includes: providing limited personal assistance and therapy services for members; lobbying for improved services for disabled people with the particular impairment they represent; lobbying for the rights of disabled people; and organising social activities for members.

\section{Umbrella organisations}

The final category in this Typology is umbrella organisations. There are in fact two such organisations, one of which is based in Malta (the Malta Federation of Organi- sations Persons with Disability; MFOPD 2012) and one in Gozo (the Gozo Federa- tion Persons with Disabilities; Attard 2012). Their set-up is different from the one described by Oliver in his Typology. The Maltese Federation is made up of partnership and parent-led organisations, some of which are also service providers. In the Gozo Federation, members include the Gozo Aid for the Visually Impaired, which has already been identified as a disabled persons' organisation, and the Ability For Disability Association, which has a good representation of people with intellectual disability (AFDA n.d.). The other members of this Federation are parent led, partnership, Church run or state run.

\section{Moving from 'for' to 'of'}

The Typology of Maltese Disability Organisations presented in this article confirms what is noted by Azzopardi (2009) and by Camilleri and Callus (2001), namely that disabled people have little to no say in the running of most organisations in the disability sector, and that historically it was organisations for disabled people that brought about changes in the disability sector in Malta. However, the number of disabled persons' organisations seems to be growing, as is the number of disabled people on committees of other types of organisations. This development is also noted by Camilleri and Callus (2001), who state that the information they received in the course of their research about Maltese disability organisations 'indicate[s] that many NGOs [non-governmental 
organisations] working in the area of disability were set up during the past four years. The majority of them involve disabled people in the main committee' (Camilleri and Callus 2001, 90).

The reasons for this recent movement towards the creation of organisations of disabled people can be attributed to a number of factors. The fact that the social model of disability was introduced from the top may mean that it took time for it to filter down to the grassroots. The enactment and gradual implementation of the Equal Opportunities Act may have contributed to the consolidation of the social model among disabled people in Malta. From being ostracised, disabled people became objects of pity and charity, while nowadays there is increasing recognition of their rights, even by disabled people themselves. Camilleri (2011) sees the increase in complaints by disabled people against discrimination as a sign that they are also increasingly asserting their rights.

Another factor that needs to be taken into consideration is that the disabled chil- dren of the parents who set up the first organisations have now grown up and are seeking their own place in the world. For example, Living Ability Not Disability, a disabled people's organisation, is an off-shoot of the National Parents' Society. It should be noted of course that parent-led organisations are still being created. STARS and the Autism Parents Association were established by parents of young disabled children. (These four organisations are mentioned in the Typology above.)

It needs to be seen whether these children will form their own organisations when they grow up. The prospects are quite encouraging for the number of organisations of to increase. The recent setting up of the Disability Studies Unit in 2012, which is headed by a disabled academic, is certainly a step in the right direction (University of Malta 2012b). Just six years earlier, Camilleri had spoken of the difficulties in posting disability studies within the University of Malta without the 'fear that disabled people can lose control over what is taught and how it is taught' $(2006,9)$.

But there is certainly no room for complacency. Disabled people's organisations are still not well resourced and still do not have as well established a fund-raising mechanism as some of the service-providing partnership organisations. There is no umbrella organisation that is entirely composed of organisations of. Nor are there any organisations that are equivalent to the Centres for Independent Living set up in countries such as the United States and the United Kingdom, which are run are by disabled people and provide services according to the needs identified by disabled persons themselves (Barnes and Mercer 2006).

It is very important that the continued development of organisations of is supported, especially in the light of Malta's recent ratification of the UNCRPD, with its emphasis on the participation of disabled people in its implementation. How this should be done has to take into account the local context. Inevitably, Malta's particular history and its culture will impinge on any future developments. The strong role played by state-run organisations and those that are within the Catholic Church, for instance, cannot be ignored. Nor can one ignore the important role that parents continue to play in the lives of disabled persons on a daily basis and their contribution to developments in the disability sector.

One approach is that of transforming organisations for disabled people into ones of disabled people 
by increasing the participation of the latter in the running of the organisation. However, this is a contentious issue and a proposal that is vehemently opposed by disabled writers such as Mike Oliver and Colin Barnes (Oliver and Barnes 2008). These objections are justified and care must be taken for any such change not to be tokenistic. To return to the analogy with the anti-racist movement referred to at the start of this article, one must beware of disabled people ending up as 'Uncle Tom' equivalents with a passive and unquestioning presence in organisa- tions for disabled people that simply serves to reinforce a status quo where it is still non-disabled people who are in control.

Another approach is to foster the development and strengthening of disabled people's organisations. Funding schemes for disability organisations, for example, can give a preference to disabled people's organisations. Non-disabled persons can also support the development of disabled people's organisations. Drake (1997), in his critique of the role of non-disabled people in the disabled people's movement, provides useful guidelines that non-disabled people (including me) should pay attention to. The three roles that he considers as being 'legitimate' for non-disabled people to pursue are exposing disabling aspects of society through research and investigation; to supply resources to disabled people's organisations, without any 'strings attached'; and to respond to specific requests for support from these organisations (Drake 1997, 644).

The most important point that emerges from Drake's paper is that non-disabled people who want to be involved in the disabled people's movement should put their skills and resources at the disposal of disabled people and act on terms set out by them. This can help ensure that disabled people and their organisations have the space and resources they need to continue developing and taking increasing control over decisions that affect their lives, on an individual and collective level.

\section{Conclusion}

This article shows that the Typology of Disability Organisations created by Mike Oliver can be adapted according to different contexts. It can also be used to exam- ine the nature of the disabled people's movement and of the wider disability sector in various countries. This can lead to an evaluation of whether the slogan 'Nothing About Us Without Us' is being implemented in practice by those working in the various organisations that make up the disability sector. Drawing up a Typology of Disability Organisations can also assist in identifying ways in which disabled people's experiences are taken increasingly more into account by those who shape and implement policy, those who provide services, and indeed anyone who in some way affects the quality of life of disabled people and their right to full inclusion and participation in the society in which they live. 


\section{References}

ADHD Family Support Group. 2012. What is the ADHD Family Support Group? Accessed October 8, 2012. Available from http://www.adhdmalta.org/adhd/about.html.

AFDA. [n.d.]. Ability for Disability Association. Victoria, Gozo, Malta: Ability for Disability Association.

Aġenzija Sapport. 2012. "Service Allocation Committee." Accessed October 8, 2012. Available from https://secure2.gov.mt/socialpolicy/SocProt/family/fsws/sapport/sapport_overview/sapport_committees.aspx.

Ameen, J. 2009. Lift Conjured up from Remains of Magic Kiosk. The Times (Malta), 44. 6th August 2009.

Archdiocese of Malta, 2012. "Diocesan Commission for Persons with Disability." Accessed October 8, 2012. Available from http://maltadiocese.org/lang/en/ secretariat-commissions/ pastoral-commission-for-disabled-persons/.

Arka Foundation. [n.d.]. Arka Foundation: Services for People with Special Needs. Ghajnsielem, Gozo: Arka Foundation.

Attard, M.R. 2012. "Disablity Organisations in Gozo." Email sent on 9th January 2012. Autism Parents Association. 2012. "Autism Parents Association - Malta." Accessed October 8, 2012. Available from http://www.autismparentsassociation.com/whoweare.htm.

Azzopardi, A. 2009. Understanding Disability Politics in Malta: New Directions Explored. Saarbrücken, Germany: VDM Verlag Dr Müller.

Barnes, C., and G. Mercer. 2006. Independent Futures: Creating User-Led Disability Services in a Disabling Society. Bristol: Policy Press.

Barnes, C., and G. Mercer. 2010. Exploring Disability. Cambridge: Polity.

Barnes, C., and M. Oliver. 2008. “"Talking About Us Without Us?' A Response to Neil Crowther.” Disability and Society 23 (4): 397-399.

Barnes, C., M. Oliver, and L. Barton, eds. 2002. Disability Studies Today. Cambridge: Polity.

Beckett, A. 2006. Citizenship and Vulnerability. London: Palgrave Macmillan.

Bezzina, F., A.M. Callus and G. Cardona. 2009. "The Quality of Life of Disabled People in Malta: Some Answers from the 2005 Census." Accessed October 8, 2012. Available from http://www.knpd.org/Issues/research.html. 
Bezzina, F, ed., 2009. Services and Benefits for Persons with Disability. St Venera, Malta: Kummissjoni Nazzjonali Persuni b'Diżabilità. Accessed October 8, 2012. Available from http://www.knpd.org/pubs/pdf/servbene.pdf.

Bonnici, A. 2005. Id-Dar Tal-Providenza Minsuġa fil-ћajja ta' Monsinjur Mikiel Azzopardi. Siggiewi, Malta: Dar tal-Providenza.

Camilleri, J., and A. M. Callus. 2001. "Out of the Cellars. Disability, Politics and the Strug- gle for Change: The Maltese Experience." In Disability, Politics and the Struggle for Change, edited by L. Barton, 79-92. London: David Fulton.

Camilleri, J. 2006. "The Genesis of Disability Studies in Malta: From a Colonial Past to an Independent Future?" Paper presented at the Disability Studies Conference, Lancaster, September. Accessed October 8, 2012. Available from http://www.knpd.org/pubs/opus/ 0609_lancaster_camilleri.pdf.

Camilleri, J. 2011. "EOA 2000 Introduction.” In EOA Report 2011. St Venera, Malta: Kummissjoni Nazzjonali Persuni B'Dizabilità. Accessed October 8, 2012. Available from http://www.knpd.org/legislation/eoa.html.

Charlton, J. I. 1998. Nothing About Us Without Us: Disability Oppression and Empowerment. Berkeley: University of California Press.

Curry, R. L. 2009. "The Exceptional Family: Walking the Edge of Tragedy and Transformation." In Disability: The Social, Political and Ethical Debate, edited by R. M. Baird, S. E. Rosenbaum, and S. K. Toombs. New York, NY: Prometheus Books.

Cuschieri, L. 1995. Monsinjur Mikiel Azzopardi 1910-1987. Malta: Lino Cuschieri. Dar TalProvidenza. 2012.

De Beco, G and A. Hoefmans. 2010. "The UN Convention on the Rights of Persons with Disabilities: An Integral and Integrated Approach to the Implementation of Disability Rights. Background Document Prepared for the International Conference 'Work Forum for the Implementation of the UN Convention on the Rights of People with Disabilities'." (18-19 November 2010, Brussels, Belgium.) Study Commissioned by the Belgian Federal Public Service Social Security.

Deaf People Association (Malta). 2012. "Deaf People Association (Malta).” Accessed March 19, 2012. Available from http://www.deafmalta.com/.

Disabled Person's Organization (Bahamas) 2012. Disabled People's Organisations. Accessed October 8, 2012. Available from http://dpobahamas.webs.com /apps/faq/\#anchor-18298-9.

Drake, R. F. 1997. "What Am I Doing Here? 'Non-disabled' People and the Disability Movement." Disability and Society 12 (4): 643-645. 
DSAM. 2012. "Down Syndrome Association (Malta).” Accessed October 8, 2012. Available from http://www.dsa.org.mt/.

Equal Partners Foundation. 2012. "Equal Partners Foundation.” Accessed October 8, 2012. Available from http://www.equalpartners.org.mt/.

ETC. 2012. "Persons in Disadvantaged Situations." Accessed October 8, 2012. Available from http://etc.gov.mt/Category/3/43/Persons_in_Disadvantaged_Situations.aspx.

FRCS. 2012. "Dar il-Kaptan: The Respite Home for People with Disabilities." Accessed October 8, 2012. Available from http://www.darilkaptan.org/.

GAD. 2012. "Gozo Association for the Deaf." Accessed October 8, 2012. Available from http://www.gadngo.com/.

Gauci, V. 2008. Investing in Our Common Good. Speech delivered on the Eve of Victory Day, 7th September 2008. Floriana, Malta: Kumitat Festi Nazzjonali.

GFN. [n.d.]. “Grupp Flimkien Naslu.” Valletta, Malta: Grupp Flimkien Naslu.

Hasler, F. 1993. "Developments in the Disabled People's Movement." In Disabling Barriers, Enabling Environments, edited by J. Swain, S. French, C. Barnes, and C. Thomas. London: Sage.

Hurst, R. 2005. "Disabled People's International: Europe and the Social Model of Disability." In The Social Model of Disability: Europe and the Majority World, edited by C. Barnes and G. Mercer, 65-79. Leeds: The Disability Press.

Hutchison, P., S. Arai, A. Pedlar, J. Lord, and F. Yuen. 2007. "Role of Canadian User-Led Disability Organizations in the Non-Profit Sector.” Disability and Society 22 (7): 701-716.

Inspire. 2012. "Inspire: The Foundation for Inclusion.” Accessed October 8, 2012. Available from http://www.inspire.org.mt/home?l=1.

KNPD. 2010b. National Policy on Employment of Disabled Persons. St Venera, Malta: Kummissjoni Nazzjonali Persuni B’Dizabilità. Accessed October 8, 2012. Available from http://www.knpd.org/pubs/pdf/Employment\%20Policy\%20EN.pdf.

KNPD. 2012a. Annual Report 2011. St Venera, Malta: Kummissjoni Nazzjonali Persuni B'Dizabilità. Accessed October 8, 2012. Available from http://www.knpdarchives.org/reports/ar_2011en.pdf.

KNPD. 2012b. "Response from MCAST to Report on Supported Employment Scheme for Disabled Persons." Accessed October 8, 2012. Available from http://www.knpd.org/pubs /pdf/socecorptmcast.pdf. 
L'Arche. 2012. "A L'Arche Community Is ..." Accessed October 8, 2012. Available from http://www.larche.org/faq-who-we-are.en-gb.25.0.news.htm.

Land, 2012. "Living Ability Not Disability (L.A.N.D.) Malta." Accessed October 8, 2012. Available from http://www.landmalta.org.

Laws of Malta. 2000. Chapter 413: Equal Opportunities (Persons with Disability) Act. Available from http://docs.justice.gov.mt/ lom/legislation/english/leg/vol_13/chapt413.pdf.

MCAST. 2012. MCAST: Malta College for the Arts, Sciences and Technology. Accessed October 8, 2012. Available from http://www.mcast.edu.mt/.

MDGM, 2012. "Muscular Dystrophy Group Malta." Accessed October 8, 2012. Available from http://www.mdgmalta.com/.

MFEI, 2011. "Budget speech 2012. Malta: Ministry for Finance, the Economy and Investment." Accessed October 8, 2012. Available from http://finance.gov.mt/ image.aspx? site=MFIN\&ref=2012_Budget $\% 20$ Speech\%20English.

MFOPD, 2012. "Malta Federation of Organisations Person with Disability." Accessed Octo-

ber 8, 2012. Available from http://www.mfopd.org/. MSSM, 2012. "Multiple Sclerosis Society of Malta." Accessed October 8, 2012. Available from http://www.msmalta.org.mt/.

MWDSA. 2012. "Malta Wheelchair Dance Sport Association." Accessed October 8, 2012. Available from http://maltawda.com/default.asp.

NPSPD. 2012. "National Parents Society for Persons with Disability." Accessed October 8, 2012. Available from http://npspd.tripod.com/.

Oliver, M. 1984. "The Politics of Disability.” Critical Social Policy 4 (11): 21-32.

Oliver, M. 1990. The Politics of Disablement. London: Macmillan. Accessed October 8, 2012. Available from http://www.leeds.ac.uk/disability-studies/archiveuk/archframe.htm.

Oliver, M., and C. Barnes. 2008. “'Talking About Us Without Us?'. A Response to Neil Crowther." Disability and Society 23 (4): 397-399.

Opening Doors. [n.d.]. Opening Doors. Valletta, Malta: St James Cavalier, Malta Arts Fund.

PHRF. 2012. "Physically Handicapped Rehabilitation Fund." Accessed October 8, 2012. Available from http://www.phrfmalta.com/.

Richmond Foundation, 2012. "Richmond Foundation Malta." Accessed October 8, 2012. Available from http://www.richmond.org.mt. 
Shakespeare, T. 2006. Disability Rights and Wrongs. London: Routledge.

Shapiro, J. P. 1993. No Pity: People with Disabilities Forging a New Civil Rights Movement. New York, NY: Times Books.

Sheldon, A., R. Traustadóttir, P. Beresford, K. Boxall, and M. Oliver. 2007. "Disability Rights and Wrongs?" Disability and Society 22 (2): 209-234.

Special Olympics. 2012. "Malta." Accessed October 8, 2012. Available from http://www. facebook.com/pages/Special-Olympics-Malta/113901471994819.

Spiteri Gingell, D. 2011. Policy on Independent Supported Living for Disabled Persons in Malta. Accessed October 8, 2012. Available from http://www.knpdarchives.org/reports/ indsupliv2011rpt.pdf.

STAND. [n.d.]. Striving Towards Ability not Disability. Mosta, Malta: Striving towards ability not disability. STARS. 2012.

"S.T.A.R.S. Shock Trauma Acceptance Reality Situations." Accessed October 8, 2012.. Available from http://starskidsmalta.com/.

The Times (Malta). 2009a. "New Home for Persons with Disability in Żejtun." The Times (Malta)", 12th November, p. 7.

The Times (Malta). 2009b. "Support group launched for amputees." The Times (Malta), 16th November, p. 7. University of Malta, 2012a.

University of Malta, 2012b. "Faculties and Deparments." Accessed October 8, 2012. Avail- able from: http://www.um.edu.mt/about/academic/faculties.

UPIAS. 1976. Fundamental Principles of Disability. London: Union of the Physically Impaired Against Segregation.

Watson, N. 2002. "Well, I Know this is Going to Sound Very Strange to You, but I Don't See Myself as a Disabled Person: Identity and Disability." Disability and Society 17 (5): 509-527.

Wilson, C. 2005. "The Other Movement that Rosa Parks Inspired: By Sitting Down, She Made Room for the Disabled". Washington Post, October 30. Accessed October 8, 2012. Available from http://www.washingtonpost.com/wp-dyn/content/article/2005/10/28/ AR2005102802449.html.

World Health Organisation. 2011. World Report on Disability. Geneva: World Health Organisation.

Wright, K. 2007. “Il-Knisja Tinvesti f’Dar Ghall-persuni b’Diżabilità.” Il-Ǵens Illum 2. June 23. 